\title{
ADDRESSING DOWNTOWN VITALITY IN A CANADIAN CONTEXT: THE CASES OF BROCKVILLE AND OAKVILLE, ONTARIO
}

by

Carly Danielle Aileen Dodds, BAH, Queen's University, 2008

\author{
A Major Research Paper \\ presented to Ryerson University \\ in partial fulfillment of the requirements for the degree of \\ Master of Planning \\ in \\ Urban Development
}

Toronto, Ontario, Canada, 2011

PROPERTY OF

RYERSON UWEVESTTYLAPATY

C Carly Dodds 2011 
$+\cdots$

1

$+$ 
I hereby declare that I am the sole author of this major research paper.

I authorize Ryerson University to lend this paper to other institutions or individuals for the purpose of scholarly research.

I further authorize Ryerson University to reproduce this paper by photocopying or by other means, in total or in part, at the request of other institutions or individuals for the purpose of scholarly research.

Signature 
1

$=$ 
I hereby declare that I am the sole author of this major research paper.

I authorize Ryerson University to lend this paper to other institutions or individuals for the purpose of scholarly research.

I further authorize Ryerson University to reproduce this paper by photocopying or by other means, in total or in part, at the request of other institutions or individuals for the purpose of scholarly research.

$\overline{\text { Signature }}$ 
$\therefore$

$=$

$\pm$ 


\title{
ADDRESSING DOWNTOWN VITALITY IN A CANADIAN CONTEXT: THE CASES OF BROCKVILLE AND OAKVILLE, ONTARIO
}

(C) Carly Dodds, 2011

\author{
Master of Planning \\ in \\ Urban Development \\ Ryerson University
}

\begin{abstract}
Downtown vitality has become an important planning issue as commercial retail evolves, development continues to sprawl, and global economic restructuring impacts North American economies. This paper reviews the literature on downtown revitalization and examines the process behind municipal planning led downtown revitalization and vitality retention approaches. Case studies of Brockville and Oakville, Ontario are used to understand a regulatory approach, in the form of a downtown community improvement plan, and a strategic approach, in the form of a downtown strategic review. In-person interviews with municipal and community officials were undertaken to gain insight into the process of these two initiatives. While both of the approaches have positive aspects, a combination of the two is identified as most favorable in addressing downtown vitality.
\end{abstract}

Key words: downtown revitalization; community improvement plan; strategic review; Ontario; Canada. 


$$
\therefore
$$

. 


\section{ACKNOWLEDGEMENTS}

I am grateful to the following people for their valuable insight and participation, without which this research would not be possible:

Dana Anderson, Director of Planning Services, Town of Oakville

Diane Childs, Manager of Long Range Planning, Town of Oakville

Suzy Godefroy, Manager, Downtown Oakville BIA

David Paul, Director of Economic Development, City of Brockville

Jonathan Faurschou, Senior Planner, City of Brockville

Andrew McGinnis, Planner II, City of Brockville

Brenda Clarke, Executive Director, Brockville DBIA

I would like to express my utmost appreciation to my supervisor, Ron Keeble, for his invaluable guidance throughout this process, and to lain Myrans for his helpful comments and suggestions.

Thank you to my family, for their love and support. 


\section{TABLE OF CONTENTS}

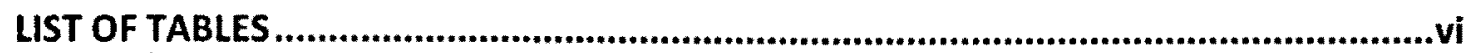

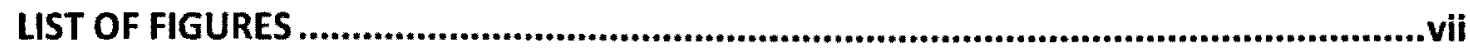

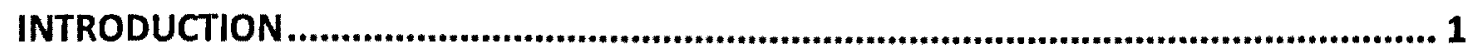

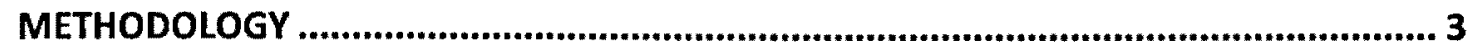

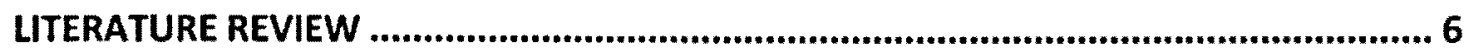

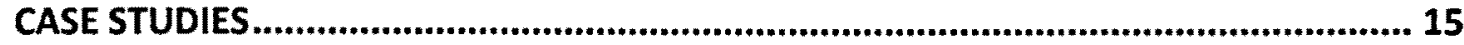

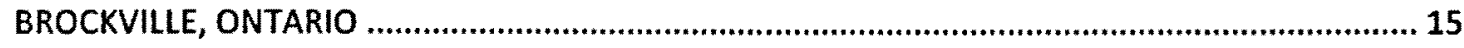

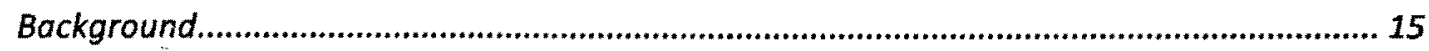

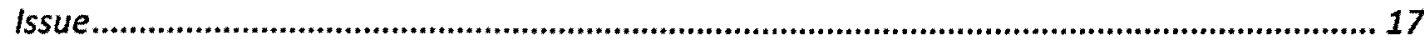

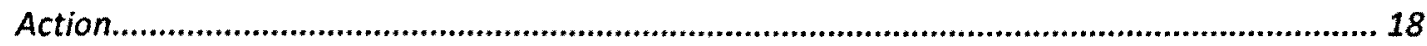

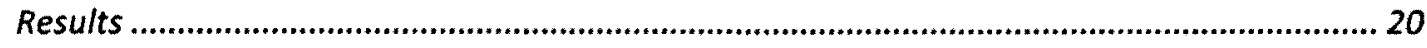

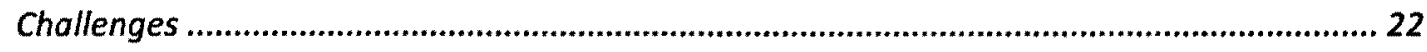

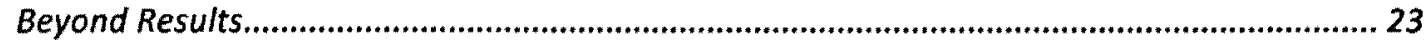

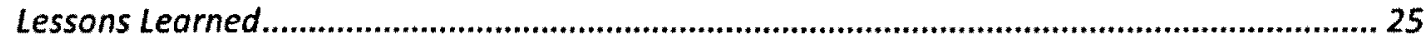

OAKVILLE, ONTARIO

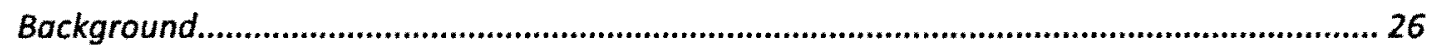

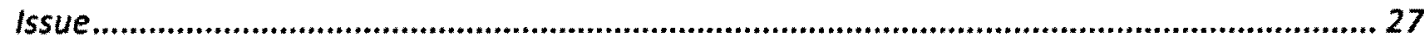

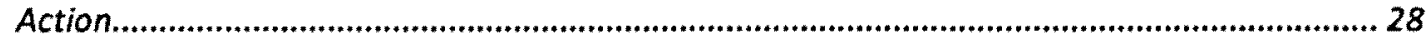

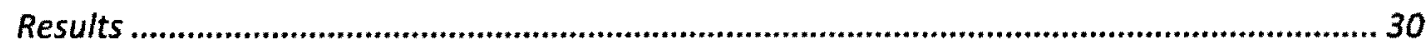

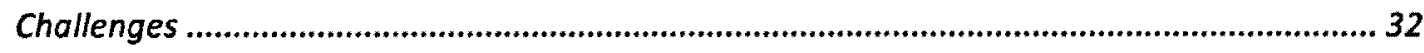

Beyond Results............................................................................................................ 32

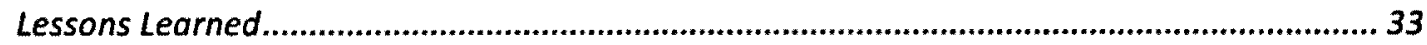

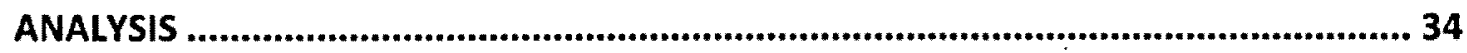

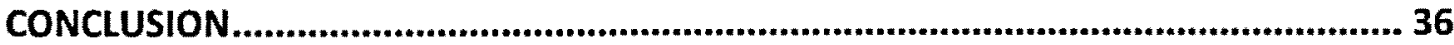

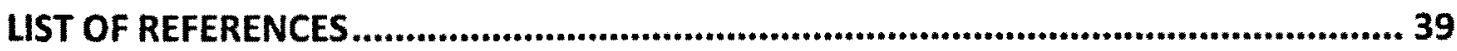




\section{LIST OF TABLES}

Table 1: CIP Program Overview and Status .19 


$$
\therefore
$$




\section{LIST OF FIGURES}

Figure 1: Downtown Development Process .............................................................................9

Figure 2: Key map of Brockville, ON..............................................................................15

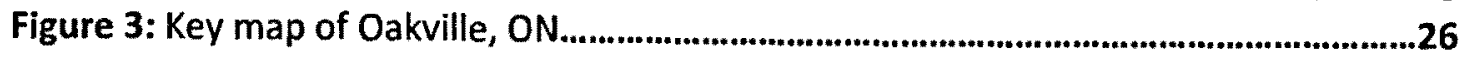


$\therefore$ 


\section{INTRODUCTION}

The downtown, or central business district, of urban centres have historically been the economic and social heart of the community. They were traditionally central locations for retail, entertainment and civic functions, and acted as a gathering place for citizens. The influence of the automobile and the growth of suburbs in the latter half of the twentieth century propelled the development of suburban shopping malls, and more recently big box power centres, across the North American landscape. The power of globalization and offshoring led to a marked decline of manufacturing and other employment bases in many North American cities and towns. Historic downtown retail areas have traditionally bore the brunt of these economic and societal changes in the form of decline. A vibrant and successful downtown is an indicator of an economically viable and culturally strong city and the issues of downtown decline and vitality retention remain important planning concerns in municipal government.

Canadian municipalities have a variety of planning tools and approaches to draw from when developing downtown revitalization or vitality retention strategies, of which two will be discussed in this paper - the community improvement plan and the strategic review.

The Planning Act allows Ontario single and lower-tier municipalities to designate community improvement project areas via by-law. Once an area is designated, a 
community improvement plan (CIP) can be developed ${ }^{1}$ and adopted by municipal council (MMAH, 2008). CIPs are meant to help municipalities address economic and other challenges facing their communities by offering "planning and financing development activities that effectively use, reuse and restore lands, buildings and infrastructure" (MMAH, 2008, p. 1). In other parts of North America, this type of approach is often referred to as a regulatory approach with incentives.

A strategic approach can also be taken, through the development of a downtown strategic review. Strategic reviews are not incentive based or policy heavy, like the CIP. Instead, they are largely centered around public engagement and consultation. This aspect allows the strategic approach to gain rich and valuable feedback from the community and identify a range of areas for future action that are deemed important for continued and improved vitality.

There is a lack of process-focused case study literature relating to downtown revitalization and vitality retention strategies, and much of the existing North American literature on downtown vitality focuses on large and small sized cities, lacking tangible studies involving mid-sized cities in a Canadian context. Using the small and mid-sized ${ }^{2}$ Canadian case studies of Brockville and Oakville, Ontario, this paper will investigate the

\footnotetext{
${ }^{1}$ Given their official plans contain provisions relating to community improvement ${ }^{2}$ Canadian mid-sized cities are defined as having populations between 150,000 and one million, and small-sized cities are those with populations of less than 150,000 people (Government of Canada, 2008)
} 
process behind two different municipal planning responses addressing downtown vitality.

While these chosen municipalities are quite different in terms of size, geographic location, and most notably, demographics, there is a similarity between Brockville and Oakville's historic downtown cores. Both cities' historic central business districts began from similarly sized village commercial districts, and are located on a central main street - Lakeshore Road in Oakville \& King Street in Brockville - surrounded by a grid pattern of peripheral streets. They are both within close proximity to water bodies (Lake Ontario and the St. Lawrence River) and have experienced suburbanization at varying scales. Additionally, these cities have experienced a similar retail evolution from downtown commercial retail to the introduction of indoor malls and more recently the development of big box retail outlets. The two case studies present different opportunities and challenges relating to downtown revitalization, so it is valuable to understand and learn from both examples, as no downtown or planning approach is ever exactly the same.

\section{METHODOLOGY}

An initial literature review using the secondary sources of books and journal articles on the topic of downtown revitalization, will provide the reader with a greater understanding of the broader issues facing a variety of downtowns, where gaps in the 
literature exist, and offer a basis for which to understand the framework behind downtown planning initiatives. The literature review will lay the groundwork for the case studies, which bring to light the process behind municipal planning responses to. issues of downtown vitality.

"The case study is a method of choice when the phenomenon under study is not readily distinguished from its context" (Yin, 2003). Case studies are often used in an evaluative context to document and analyze the process behind what is being studied, as well as the associated implementation processes. The advantage of case study as a research method is that it can produce more detailed information and understanding than what could be gained from other methods such as surveys. It also allows the researcher to present data collected from multiple methods, such as interviews and document review utilized in this research paper, in one cohesive analysis (Neale et al., 2006).

The Brockville case study will specifically examine the process behind the City's Downtown Community Improvement Plan. It is acknowledged that there are other policies, including the Brownfields Community Improvement Plan and section 4.2 of the new Brockville Official Plan, that relate specifically to the historic downtown area. However, for the purposes of this paper, only the Downtown Community Improvement Plan will be examined. Primary research, in the form of in-person interviews, was 
conducted with Brockville's Senior \& Intermediate Planners, Economic Development Director $^{3}$ and Executive Director for the Downtown Business Improvement Area.

The Oakville case study will examine the process behind the recent Downtown Oakville Strategic Review. Primary research, in the form of in-person interviews, was conducted with Oakville's Director of Planning, the Manager of Long Range Planning and the Manager of the Downtown Business Improvement Area. The professional responses gained from interviews in both locations have shaped the author's interpretation of the process behind Brockville's Community Improvement Plan and Oakville's Strategic Review.

The case studies are organized as seven sub-sections. First, a background on the city/town will be provided for context. Second, the issue(s) spurring the revitalization planning policies are explored. Third, the actions taken by the municipalities are described. Fouth, the results of these actions are discussed. Fifth, challenges associated with the processes are provided. Sixth, long term implications are examined by looking beyond the results. Finally, the seventh discusses lessons learned. Following the case studies, a comparative analysis will be conducted identifying the strengths and weaknesses of each approach in relation to the case study, as well as recommendations for future research.

\footnotetext{
${ }^{3}$ This interview was conducted via phone
} 


\section{LITERATURE REVIEW}

Academic literature on the forces influencing the decline of historic central business districts, or downtowns, in American cities is plentiful (Faulk, 2006; Brueckner, 2000; Zeilinbach, 2000; Bright, 2000; Grogan \& Proscio, 2000). Demographic shifts to the suburbs and the resulting decline in the central urban population are important factors when looking at large cities, particularly inner city American downtowns (Bright, 2000; Grogan \& Proscio, 2000). Increased demand for post-war housing, the rise of the automobile, and single-family home financing availability in the form of mortgages, facilitated sprawling development outside the cities' traditional urban boundary. As suburban growth increased, many historic downtowns and older neighbourhoods were negatively affected (Burayidi, 2001; Faulk, 2006). Zielenbach (2000), and Frieden \& Sagalyn (1989) look at downtown decline in large cities, while Burayidi (2001) and Robertson (1995 \& 2001) add to the literature on small city (populations under 50,000) downtown decline, while also comparing strategies and experiences with large cities (Robertson, 1999). However, mid-sized and suburban cities through a Canadian perspective are not widely included in this body of research.

The rise of urban sprawl and suburban development coincided with the popular development of large shopping centres within the suburban landscape (Seidman, 2002; Huang et al, 2002) and the later development of downtown malls and marketplace conversions (Filion \& Hammond, 2008). The emergence of suburban malls led many large retailers, which previously anchored downtown central business districts, to follow 
their clientele to the suburbs. Smaller 'mom and pop' shops faced stiff competition with large scale discount stores, and combined with the rise of automobile transportation and further suburban growth, ultimately led to the demise and closing of many businesses who simply couldn't compete (Rucker, 2001; Zielenbach, 2000).

There is a wide body of existing literature that deals with the local impacts of big box retail, but the majority are based on a singular case study, and usually refer to an American context. Huang et al. (2002), Franklin (2001) and Stone (1997) discuss the local retail restructuring that results from big-box and Wal-Mart style development in cities. The foci of their argument include the loss of retail employment elsewhere in the city, a decrease in the overall number of retail establishments and most importantly for the purposes of this research, the decline of downtown shopping areas. Based on case studies, mass discount merchandisers in the form of big box retail, are responsible for the largest and most recent adverse impacts on rural communities (Stone, 1997). Goetz \& Swaminathan (2004) analyze whether the opening of Wal-Marts, in what they call the "Wal-Mart effect", can influence community-wide poverty rates. Negative outcomes include a break up of civic capacity as a result of many local entrepreneurs and community leaders having to close shop. The majority of these studies are limited by their focus on data from a small selection of areas (e.g. rural lowa counties in Stone (1997)).

Jones \& Doucet (2000) take a Canadian approach and examine Greater Toronto Area big 
box and power centre growth and impacts, which is useful for mostly analytical purposes in a Toronto context. Nowhere in the above-mentioned works is the topic of big box impacts specifically on existing historical downtowns in suburban cities and towns addressed. Much of the research is focused primarily on metropolitan cities and retail outmigration to the suburbs, and ignores historical downtown commercial districts within present day Canadian suburbs. Both case studies have experienced the introduction of big box retail, with varying outcomes on their historic downtown cores.

Major revitalization issues facing downtowns of small, non-suburban cities are highlighted by Robertson (1999) and include: attracting new development (particularly residential), attracting people on evenings and weekends, competition from discount stores and malls, vacant space and parking availability. These issues are echoed in the works of Hechesky, (2005), Filion et al. (2004) and Burayidi (2001).

Illustrated in Figure 1, Faulk developed an eight-stage model to "describe the economic and spatial changes occurring in aging downtown areas and surrounding neighbourhoods" (2006, p.631). Stage 1 exemplifies a 'traditional' monocentric city with a central business district of concentrated retail, commercial and industrial uses, surrounded by compact residential areas. Stage 2 signals the emergence of a polycentric city, and outmigration to the suburbs. As population in the historic downtown declines, so does the retail and commercial traffic, Stage 3 . Stage 4 is indicated by high levels of 
Stage 1:

Commercial, retail, and government center.

Stage 2:

Decline in residential area surrounding downtown.

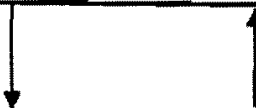

Stage 3:

Decline of retail \& commercial space.

Stage 4

High level of vacancies and abandonment

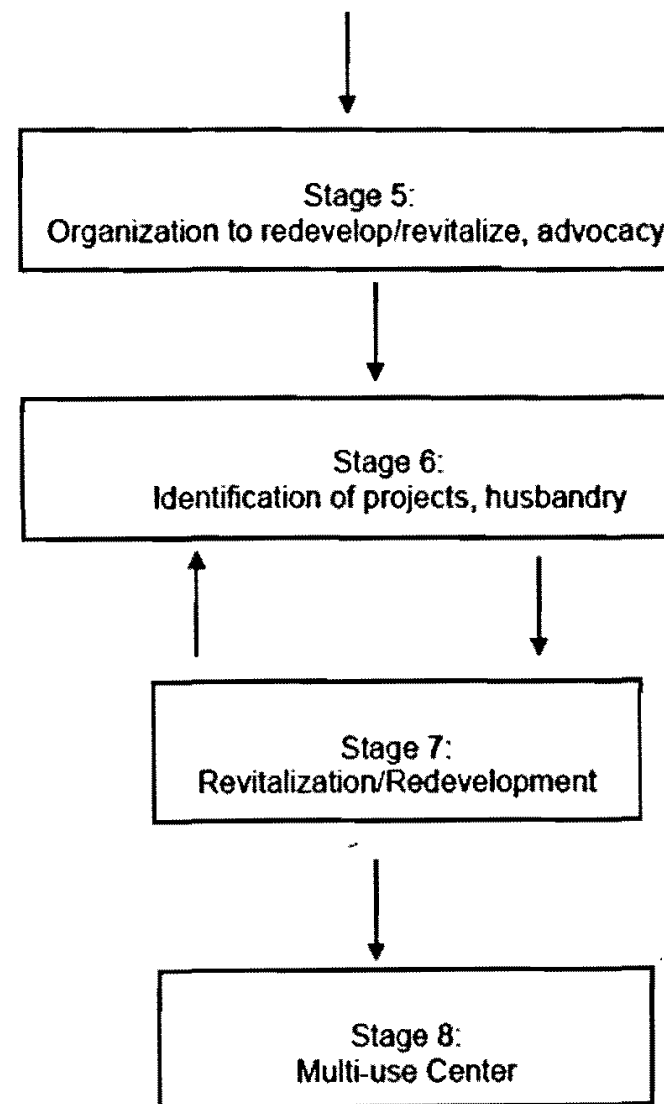

Figure 1. Downtown Development Process (Faulk, 2006 p. 631) 
vacancy in the downtown area, as retail and commercial uses move out to indoor shopping malls and commercial strip plazas. The need to address increased vacancies and the overall decline in the downtown is recognized by the community in Stage 5 . In Stage 6, identification of revitalization projects is undertaken and new uses and financing options are explored. Stage 7 is the actual redevelopment and revitalization process, which can be a slow and gradual progression. Finally, Stage 8 is the successful culmination of the revitalization process. The downtown is vibrant and multi-use, with low vacancy levels and increased variation of activities.

While Faulk (2006) offers a picture of downtown evolution in his process map, Robertson (2001, 1999 \& 1995), Burayidi (2001) and Moulton (1999) all offer policy approaches and strategies for downtown revitalization. Modern revitalization strategies can be broadly categorized into six areas: pedestrianization, historic preservation, waterfront development, cultural \& special activity generators, office \& housing development, and parking \& transportation enhancement.

Pedestrian malls, or outdoor pedestrianized streets, emerged as a reaction to the suburban shopping mall. It was a strategy employed to revitalize an eroding retailing base in the downtown through the creation of automobile-free, more pedestrianfriendly shopping streets with the idea that if you improved the pedestrian environment, this would attract more business (Frieden \& Sagalyn, 1989; Robertson, 
1993, 1995, 1997, Filion \& Hammond, 2008). Other aesthetic strategies to draw pedestrians include improving the streetscape through the addition of flower boxes, street trees and other landscaping, benches, public art, attractive lighting, and defined sidewalks (Faulk, 2006). While many BIAs employ these aesthetic strategies today, pedestrian malls have been largely unsuccessful in the long term, unless located in an area with a consistently high volume of pedestrian traffic, such as a university campus, or office district. Both the Brockville and Oakville downtown BIAs regularly undertake beautification tactics, and neither municipality has developed a substantial outdoor mall, which will likely be beneficial for future vitality, as most have proved to be unsuccessful in the literature.

Historic downtowns inevitably have historically significant buildings as a result of their age, and these buildings "represent the most visible manifestation of a downtown's image" (Robertson \& Ryan, 2004, p.18). Unique architectural styles and features from different eras add to the charm of a main street downtown and enhance a sense of place. In many cases, downtowns in the process of revitalization often have what Robertson describes as "white elephants" (1999, p.275). These are large vacant buildings in strategic locations within the downtown that create an eyesore and negatively impact the surrounding area in terms of streetlife and sense of place. As such, these buildings are often centerfold in revitalization efforts (Faulk, 2006). Rypkema (1994, 2003, \& 2008) looks beyond the importance of heritage preservation in terms of future economic benefits and retaining a sense of place to the environmental 
benefits from a smart growth and sustainability perspective - it makes more sense to retain and enhance the pedestrian-focused compact downtown form.

Strategies involving waterfront development have been popular since the 1970s, and many historic downtowns, including Oakville and Brockville, are located within close proximity to water features, which were likely instrumental in their initial foundations for transportation access (Roberston, 1995). McBee (1992) and Craig-Smith (1995) classify waterfront use into three categories - water-dependent, water-related and water-enhanced. Downtowns often use proximity and access to water to distinguish themselves from suburban areas and really capitalize on unique natural and built heritage. An underutilization of water attributes is a major issue in revitalization, and as such, both public access to water and private development have become popular strategies to increase sense of place and economic functions (Breen \& Rigby, 1994; Robertson, 1995; Robertson \& Ryan, 2004).

Culture is one of the cornerstones of tourism. The importance of culture in a city has been discussed in the literature for decades. Not only does it draw people to a city, but culture also influences where people decide to live and work (Florida, 2002; Grodach \& Loukaitou-Sideris, 2007). Revitalization strategies relating to cultural developments have largely been focused around special activity generators in an American context such as marketplaces (Sawicki, 1989; Robertson, 1997), sports arenas (Baade \& Dye, 1988; Rosenthaub et al., 1994; Chapin, 2004), and convention centres (Robertson, 1995, 
Sanders, 1992 \& 2002). Canadian context is lacking within this research area, particularly relating to smaller sized downtowns, and many regulatory planning approaches fail to meaningfully incorporate the cultural aspect in vitality related strategies.

Downtowns are diversifying beyond retail functions, and office and housing development have emerged as strategies to drive revitalization. Increasing the residential base of a downtown has a positive snowball effect on the surrounding area. Residential housing, as well as office developments, provide an added customer base for shops and restaurants, while also increasing foot traffic and contributing to a lively local atmosphere (Moulton, 1999; Robertson, 1995, 1999). Additionally, an increase in residential population increases the demand for diversity in goods and services and extends the 'open hours' of a downtown (Faulk, 2006).

Birch (2002, p.10) identifies six approaches to undertake in order to encourage residential housing developments in the downtown. They are as follows: (1) Fostering adaptive reuse of office buildings, warehouses, factories and stores; (2) building on "found" land, such as a reclaimed waterfront or remediated brownfield sites; (3) redeveloping public housing; (4) Crafting mixed use projects with new construction; (5) targeting niche markets, such as senior or student housing; and (6) using historic preservation to forge special identity. Some of these approaches can be identified in a strategic review process, and be facilitated via CIP incentives. 
Transportation is an inevitable issue when reviewing redevelopment strategies. Enhancement of transportation in the downtown has largely involved improving parking provision, improving physical road conditions and maintenance, and altering transportation design to address congestion and safety (Robertson, 1995). Parking availability is often seen as a major issue to downtown consumers, and as such, must be recognized as a public and commercial concern when undertaking a downtown vitality assessment or developing a revitalization program.

Hechesky (2005) analyses the often cited US Main Street Program (Faulk, 2006; Rucker, 2001; Mulkeen, 1997; Franaviglia, 1996), which employs an approach that focuses on attracting niche businesses that bring shoppers to Main Street, design control that reflects a concern for historical buildings, marketing cooperation among Main Street merchants and an emphasis on innovative events that draw people to Main Street. Current academic research has yet to explore in-depth Canadian examples using the Main Street, or an equivalent, approach. This type of program, if successful in a Canadian context, could be integrated into municipal strategies in the future.

The literature focusing on strategies related to downtown revitalization has predominantly been inclusive in terms of city or town size. Thus, there seems to be an assumption that all types and sizes of downtowns would follow the similar methods in developing revitalization strategies. This one-size-fits-all approach is useful in gaining broader knowledge, but the uniqueness of every downtown - geographically, 
demographically, and historically - requires a more tailored method. The policy approaches and strategies discussed above are only guidelines for revitalization and much of the literature lacks Canadian examples of successful real-world intervention. There is opportunity for further study within a Canadian context, looking specifically at the process behind downtown vitality retention projects and evaluating the success of varying approaches to better inform future municipal action and direction.

\section{CASE STUDIES}

\section{BROCKVILLE, ONTARIO}
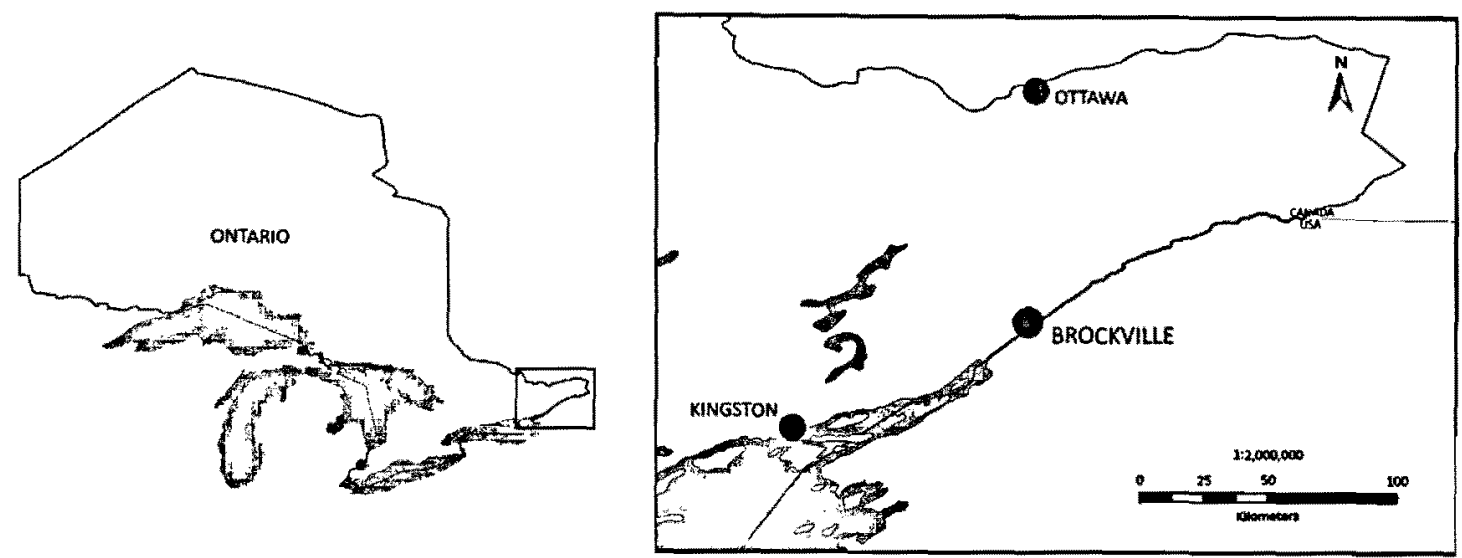

Figure 2: Key map of Brockville, ON

\section{Background}

Known as the "City of the 1000 Islands", Brockville is located on the St. Lawrence River, about halfway between Toronto and Montreal along the Highway 401 corridor. It is about one hour from Kingston to the west and Ottawa to the northeast. Brockville is a 
single tier municipality with a population of 21,957 and a median income per household of $\$ 46,071$ (Statistics Canada, 2006).

Brockville is one of Ontario's oldest communities, and is renowned for its historic charm. Founded in $\mathbf{1 7 8 5}$ as a Loyalist community, it was not known as Brockville until the summer of 1812, when the name was changed from Elizabethtown, in honour of General Isaac Brock. Brockville became Ontario's first incorporated town in 1832, and the historic downtown core still retains many original buildings dating back to the $19^{\text {th }}$ and early $20^{\text {th }}$ centuries (Grant, 2009). Canada's first railway tunnel, opened in 1860 , snakes under the city for 1700 feet, exiting just south of the downtown main street, King Street, at the waterfront (Brockville Museum, 2000).

Brockville's strategic location on the St. Lawrence River has played an important role in its development. Water access, and the close proximity to the Grand Trunk Railroad for exporting purposes, drew a multitude of industries to the waterfront including the McNaughton Brewery, the R.P. Coulton Foundry, and the James Smart Manufacturing Company. Today, the industrial and manufacturing sector has generally relocated to the northern part of the City for access to the 401, and the waterfront, historic core and natural heritage of the Thousand Islands has become a huge tourist draw to the City (Brockville Museum, 2000). 
Issue

As illustrated in the literature review, downtown vitality is an important issue facing countless municipalities across North America, both large and small. Brockville's historic downtown has evolved with market, industry and demographic changes in the last century and the City itself and has undergone significant restructuring in regards to its economic base in recent years.

Formerly an industrial economy, Brockville is now seeing a decline in manufacturing as a result of globalization and the offshoring of industry. Services and tourism are now primary industries for the City. Brockville has also experienced modest residential sprawl and the development (and re-development) of an uptown mall and big box strip that continues to expand. This pattern of economic restructuring, combined with the emergence of big box commercial retail is echoed in numerous other Canadian small cities, which makes this example that much more relevant.

The City has made commercial revitalization in the downtown area a primary goal in its Community Improvement Plan (City of Brockville, 2007). While Brockville's main street downtown area is certainly not "dead" in an economic or cultural sense, improvements to the overall vitality of the area are advantageous for sustainable future success. 


\section{Action}

Overall, the interview participants do not feel that the up-town mall built in the 1970 s, nor the recent big box retail developments in the north end of the City, have had a large impact on the downtown commercial area. It was identified by more than one individual that there are faithful customers who frequent the downtown for specific shops and expertise, and that while some customers will "price shop" and end up buying from a cheaper big box store, the City has not seen a substantial commercial exodus from the downtown as a result of this competition. However, in 2007, the City did develop a Community Improvement Plan (CIP) for the downtown to address the issue of revitalization.

The Community Improvement Plan itself was initiated by Brockville's Planning Department, with the Director of Planning noted as a champion of the process. By conducting background research on other communities' downtowns and CIPs, the Director of Planning was able to gain buy-in from the Economic Development Department, the Treasury Department and the City Manager's Office. The Director's motivation was an identified need within the community for a catalyst in the revitalization process and believed that need could be addressed via a new planning policy. Additionally, Brockville had been involved in an Ontario Ministry of Municipal Affairs and Housing pilot project called the Leeds \& Grenville Resource Jump Team. Through this process they looked at a number of the downtowns in the United Counties 
of Leeds \& Grenville and in the final report, a CIP was touted as an initiative or tool that could improve development in the downtown.

Creating the Plan was a joint effort between city staff from the Planning Department, Treasury Department, Economic Development Department and the City Manager's Office. An external consultant with expertise on other downtown-focused CIPs was appointed to direct and develop the different aspects of Brockville's own downtown CIP.

Promoting and encouraging commercial revitalization in the downtown area is identified as the primary goal of the CIP. In order to facilitate this, the City has developed a number of financial incentives, through the CIP, to promote the construction and rehabilitation of residential development and the conversion of upper-floor commercial buildings into residential space in the downtown (Section 4, CIP for Downtown Brockville). Below is a table that gives an overview of the original three incentive programs developed in the CIP to encourage revitalization and the status of the programs at the present time.

Table 1: CIP program overview and status

\begin{tabular}{|l|l|l|}
\hline Program Name & Description & Status \\
\hline $\begin{array}{l}\text { Tax Increment Equivalent } \\
\text { for Rehabilitation and } \\
\text { Redevelopment (TIERR) } \\
\text { Grant Program }\end{array}$ & $\begin{array}{l}\text { Aimed at existing buildings and vacant or under- } \\
\text { developed sites }\end{array}$ & $\begin{array}{l}\text { Implemented } \\
\text { Provides a monetary grant in the form of tax rebate } \\
\text { to property owners who undertake improvements } \\
\text { or redevelopment that would result in an increased } \\
\text { property assessment } \\
\text { Grant amount is dependent on the municipal } \\
\text { portion of property tax increase as a result of the } \\
\text { improvements } \\
\text { Minimum construction value of } \$ 5,000\end{array}$ \\
$\begin{array}{l}\text { (Property } \\
\text { owners must } \\
\text { register an } \\
\text { intent to } \\
\text { participate by } \\
\text { June 30, 2011) }\end{array}$ \\
\hline
\end{tabular}




\begin{tabular}{|c|c|c|}
\hline $\begin{array}{l}\text { Heritage Signage Grant } \\
\text { Program }\end{array}$ & $\begin{array}{l}\text { Meant to stimulate property improvements, } \\
\text { increase building visibility and encourage visual } \\
\text { continuity via a 'heritage' theme for building } \\
\text { signage } \\
\text { Grant of } \$ 1,000 \text { or } 50 \% \text { of the cost of the sign } \\
\text { professionally produced, costs eligible for a grant } \\
\text { are limited to hard costs and labour - taxes, pre- } \\
\text { consultation and mock-up costs are not eligible } \\
\text { - If 'home-made' of professional quality, eligible costs } \\
\text { for a grant are limited to hard costs, excluding } \\
\text { labour and taxes } \\
\text { One grant per place of business }\end{array}$ & $\begin{array}{l}\text { Discontinued as } \\
\text { of October } 10, \\
2007 \text { following } \\
\text { a resolution of } \\
\text { Council }\end{array}$ \\
\hline $\begin{array}{l}\text { Building \& Plumbing } \\
\text { Permit Fee Grant } \\
\text { Program }\end{array}$ & $\begin{array}{l}\text { Offers a grant equivalent to the Building Permit } \\
\text { Fees and Plumbing Permit Fees paid for permits } \\
\text { issues within the priority areas designated in the } \\
\text { CIP } \\
\text { Meant to stimulate and encourage new } \\
\text { development and existing property improvement } \\
\text { Building and plumbing fees are required at the time } \\
\text { of building/plumbing permit issuance, however } \\
\text { grants will be processed immediately upon receipt } \\
\text { of these fees by the City }\end{array}$ & $\begin{array}{l}\text { Implemented } \\
\text { (Program in } \\
\text { effect until June } \\
30,2011 \text { ) }\end{array}$ \\
\hline
\end{tabular}

Source: Community Improvement Plan for Downtown Brockville, Schedule B-1, B-2 \& B-3

\section{Results}

In all accounts, the public has responded well to the CIP in principle, however, results on the ground seem to be varied. Four projects have signed agreements with the City under the CIP, utilizing the associated tax increment financing. These include waiving of building permit fees and development charges. The CIP is also the only legal way (under Section 28 of the Planning Act) to offer bonusing in the community, which is an additional draw for developers. The response to the Tax Increment Equivalent for Rehabilitation and Redevelopment (TIERR) Grant Program has been small. The TIERR is a grant program that offers tax rebates for five years of $100 \%$ of the increase in municipal realty taxes to those owners who make improvements to or redevelop their properties in such a way that will increase their property assessment. However, it has not been a 
widely popular program for existing properties because there is also no guarantee that a specific improvement will increase the property assessment, which is why it is more popular with new developments. Additionally, the amount of tax rebates over five years would be substantially more on a new development versus an improvement to an existing structure.

A waterfront condominium development aimed at the $45+$ age bracket is currently under construction and will bring 600 new residents to the downtown waterfront in the next three to five years. This development has been a direct result of the CIP in terms of the effective incentives to draw and support new development.

While the $\mathrm{ClP}$ and its associated incentives seem to be stimulating some new development in the downtown area, the revitalization of existing buildings seems to remain stagnant. There are still several for lease and vacancy signs on King Street, including what Roberston (1995) would refer to as a "white elephant" - a large, vacant, former retail outlet in a prime location along the main street. There have been community efforts to improve the visual aspect of this "white elephant" by utilizing youth in the area to paint art boards in the windows, however this is seen as just a band-aid fix. The BIA is active in beautification tactics, and visually the downtown is pleasant. 


\section{Challenges}

One of the major challenges faced in the CIP process was getting the initial buy-in and co-operation from the Municipal Property Assessment Corporation (MPAC) in regards to the TIERR grant program. The program requires MPAC to conduct an assessment before the rehabilitation or redevelopment of the location begins and another assessment once the work is finished. This has been problematic in the past due to long wait times for both initial and final assessments.

While this aspect of the CIP is advantageous for new developments, as mentioned previously, smaller existing units such as rental housing over a downtown store will not have the same returns. MPAC does not recognize simple improvements such as paint and small repairs and the City also does not include the cost of personal labour when the property owner provides the total cost of the project. Those in the community who have taken part in the program, particularly with small existing developments, have not been satisfied with the change in assessment value and total return on their improvement investment. The financia! incentives do not seem to be even across development scales. It seems as though these CIP grants are more beneficial for largescale and new developments, as opposed to smaller and existing improvement-based construction. A major challenge is trying to balance the interests of all sectors of the community. 
Frequent management changes in the Downtown Business Improvement Area have impacted the ability of the DBIA to gain full buy-in from all the businesses in the downtown area. Management changes have stabilized at present, and there is hope that this will allow for a more cohesive and effective future in terms of the DBIA's marketing strategies.

No challenges were identified in bringing together different staff departments and coordinating with outside consultants, and overall it appears that the City worked as a cohesive unit for the betterment of the community. Council has been very supportive of the project as a whole, and when it comes under review this year, City staff expects that Council will approve to extend the CIP for an unspecified time frame.

\section{Beyond Results}

The global economic downturn negatively affected Brockville, and this in turn impacted the revitalization strategies outlined in the CIP. The Economic Development Department acknowledges that Brockville has gone through a two-year period of struggle, but the recent development projects in and around the downtown area seem to have revived the relevancy of the CIP.

While Brockville's intentions with the introduction and implementation of the CIP have been admirable, there has been a lack of public consultation and participation 
throughout the process. Had there been more input from the property and store owners in the downtown, the City would have understood earlier that the Heritage Signage Grant Program would not be well-used and they could have eliminated it from the original CIP. This would have saved staff time and money paying consultants to develop a program that seems to have been doomed from the beginning. Additionally, public or stakeholder consultation may have identified the issue of scale in the TIERR program, which is more tailored to new and larger scale developments, as opposed to improvements to existing buildings. In terms of drawing new development to the area, in particular residential development in close proximity to the main street, the TIERR and Building \& Plumbing Permit Fee Grant Programs have been successful. This is demonstrated in the new condominium and other developments currently under construction in the downtown that were identified as a direct result from having these types of grants available.

As with all things, and particularly with policy, there will always be room for improvement and adjustment. The primary goal of the CIP is to promote and encourage commercial revitalization in the downtown area. While it is acknowledged that Brockville is going through a transition period, it does not appear that the CIP has effectively advanced its desired goal at this point in time. Revitalization takes years, and there is hope for the future as major housing projects and other catalysts of commerce, culture and change begin to develop in the downtown area. 


\section{Lessons Learned}

Brockville's example is applicable to other communities in several ways. Rurally based (significant distance from a major urban centre) small cities and towns have unique issues in drawing new development. Financial incentives can become a major factor in attracting and creating new development, as was the case in Brockville. However, municipalities need to also consider the scale at which they are targeting these grantbased strategies to ensure that both small and existing developments will also benefit, particularly if revitalization as a whole is the major goal. The lack of public and stakeholder consultation prior to the development of Brockville's CIP likely contributed to the development of the ineffective Heritage Signage Grant Program.

This is useful to other municipalities because it highlights the importance of understanding the needs of the community before introducing policy-led incentives that may end up unused. Brockville is continuing to undergo a transition period economically, and with further public and stakeholder consultation, there is potential to update the current CIP to better reflect the needs of the downtown community as a whole - commercially, residentially and culturally. 

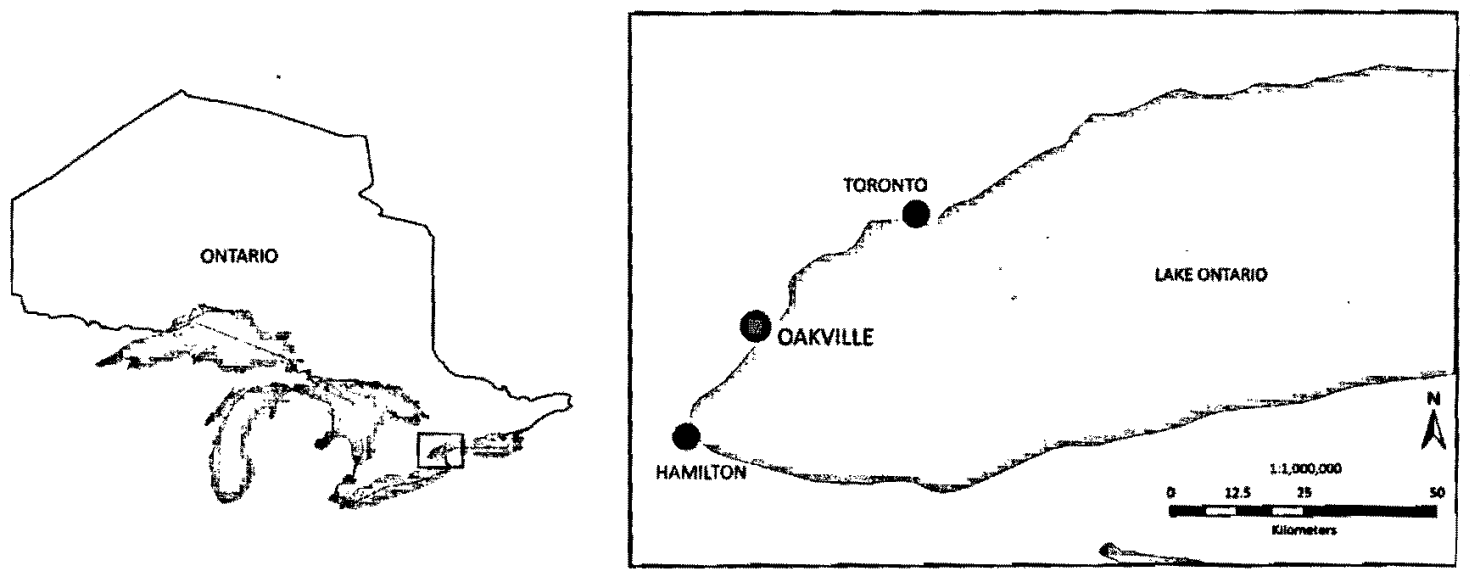

Figure 3: Key map of Oakville, ON

\section{Background}

Oakville is considered a western suburb of Toronto, and is located between Mississauga and Burlington on the north shore of Lake Ontario. It is part of the Regional Municipality of Halton, which also includes Burlington, Milton and Halton Hills. The title Town of Oakville can be slightly misleading because its size is actually equivalent to that of a midsized city at 165,613 residents. It is one of the more affluent communities in Ontario with a median household income of $\$ 92,394$ (Statistics Canada, 2006):

The area that is known today as Oakville was originally Mississauga Indian territory, purchased in 1820 by the Crown, before being auctioned off to William Chisholm in 1827 (Pope, 1877). Initial industries within the Town were shipbuilding, timber shipment, wheat farming and basket weaving. The town was industrialized with the development of oil refineries, including Petro-Canada and Shell Canada, both of which 
are now closed. Several manufacturing plants located here, the largest of which was Ford Motor Company, which included its Canadian headquarters. In 1962 the town merged with the neighbouring communities of Bronte, Palermo, Sheridan and Trafalgar Township to become the Town of Oakville that is recognized today (Town of Oakville, 2010, p. 2). As a result of this agglomeration, the Town has more than one historical central business districts, however, this paper will focus on the historic Downtown Oakville area.

Issue

Maintaining a healthy and successful downtown is something cities and towns large to small strive for. Oakville's population has more than doubled in the past thirty years and is a classic example of urban sprawl. Proposed greenfield development in North Oakville will increase the Town's overall population and extend the low-density residential that is prevalent throughout Oakville's urban form. Academic literature consistently correlates suburban expansion with downtown decline. Oakville is perceived to have a successful historic downtown, and as the Town develops further, retaining the vitality of the downtown is an issue that must be addressed for the continued sustainability of the area. The Town has already acknowledged the importance of their downtown vitality in the new Livable Oakville Plan, and has conducted a special study of the downtown areathe Downtown Oakville Strategic Review. 
Oakville's new official plan, Livable Oakville, was approved in 2009. During the public engagement process of the plan, issues relating to the improvement of the downtown were brought up by the community, town staff and Council. Section 25 of Livable Oakville recognizes Downtown Oakville as a growth area and reinforces the goal for the downtown to "remain a major downtown area for the Town, providing a broad variety of commercial, office, entertainment, cultural and residential uses" (Section 25.1).

The Downtown Oakville Strategic Review (DOSR) came out of the Livable Oakville process, and was a multifaceted study that involved a variety of Town departments. This approach was chosen because of its advantages in terms of public engagement and consultation, and its ability to gain a richer understanding of what is being done well, what needs improvement, and what is missing in the downtown. Council and municipal staff were identified as champions of the process, with Council being supportive and staff being dedicated to the process and outcome of the review. Livable Oakville had already confirmed the land use and intensification policies, and the role of the DOSR was to go beyond these to address other elements of concern that related to the vitality of the downtown. These included issues regarding the retail and commercial sector, public, recreational and cultural facilities, heritage concerns, transportation and infrastructure, connectivity to the waterfront and accessibility. 
In partnership with a facilitation consultant, three levels of consultation were undertaken over a period of six months. The first was with a group of small key stakeholders that included Ward Councilors representing the area, key managers and directors from staff departments and key representatives from the BIA and residents association. Together, they determined the terms of reference for the study and were responsible for reviewing and offering feedback on key documents.

The second level was the medium stakeholder group, which included representatives from the Historical Society, Heritage Oakville, Conservation Halton, a variety of advisory committees including Traffic, Transit, Accessibility, Seniors and Cultural, the Mayor and Ward Councilors, a number of surrounding residents associations and a broader representation of Town departments. This group was involved in the two interactive workshops where a SWOT analysis and strategic direction for the action plan was developed.

The third level of consultation attempted to reach more of the general public and those property owners who may live outside of the community. A confidential online survey was developed for property owners in the area and interested residents were invited to offer feedback on the strategic review process and the downtown in general via email response. A meeting with the youth advisory committee was also undertaken in this level to gain further perspective from diverse groups. A public open house was also conducted for residents to confirm the direction of the strategic action plan. 


\section{Results}

The result of the DOSR was the Downtown Strategic Action Plan, an eight-page document developed through the public engagement process to guide change in the downtown. The action plan is grouped into three themes - inspire, connect and protect. Inspire encompasses those strategies that will essentially direct and guide future development and include actions relating to: urban design guidelines, the Centennial Square facilities (A Town-owned major arts and culture facility in the downtown), accessibility and safety, and tools and incentives. Connect deals with identifying potential opportunities and improving existing assets in order to maximize long-term success. These actions included: a transportation, access and mobility evaluation, examining downtown culture, a retail strategy, re-evaluation study of Towne Square, and exploring youth initiatives. Protect also deals with existing assets and focuses on strategies to protect the successful and historical attributes of the downtown through actions such as possible communication and coordination models, a heritage conservation district, and a study of the soon-to-be-vacant Post Office site.

For each action, a "what", "why", "who" and "when" are listed which offers direction and ownership of the strategies. There was an extensive amount of direction that came out of the public engagement process, as well as an understanding that not every issue could be addressed in a short amount of time. As a result, the Town placed priorities on certain actions, which is noted in the "when"s, listing implementation as either one to two years, or three to five years. There is also a table at the back of the action plan that 
lists identified strategic initiatives that have already been, or will be, undertaken through other municipally led actions. For example, ensuring safe pedestrian and bicycle activity in the downtown was an identified initiative in the strategic review process and the associated action is labeled as falling under the ongoing implementation of the Active Transportation Master Plan.

The Action Plan was released in August 2010, so there has not been a significant amount of time for substantial results to occur. Several studies are underway that relate to topics discussed in the Review process, such as the Parks, Recreation \& Library Master Plan update that has a specific review on the downtown Centennial facilities. The Planning Department has also drafted a terms of reference for the heritage district conservation designation, so it is apparent that action items are being currently addressed. The majority of the actions had timelines of three to five years, so a thorough evaluation of the outcome of the projects resulting from the Plan cannot be undertaken at this time. However, in looking at the process from a public engagement perspective, it is apparent that the DOSR has been incredibly successful in gaining input from the community and key stakeholders, and that there has been a general consensus between the Town and the community on downtown priorities. 


\section{Challenges}

One of the biggest challenges identified in the process was the coordination and bringing together of all the appropriate Town staff, as well as the stakeholders. The stakeholders represented such a diverse group of interests and expertise, and the consultant was challenged to encourage participation in a way that made those involved feel as though they were contributing in a meaningful way.

The Review process addressed more than was originally anticipated by the Town, and with that comes the challenge of resource limitation. While the contributions in terms of actions were positive, they were also extensive and wide ranging, which can be difficult to address in terms time frames, staff resources and budgets. Overall, there was a general feeling of success and satisfaction that the DOSR addressed the concerns initially brought forward in the development of Livable Oakville and that the resulting Strategic Plan covered the scope of issues raised in the public engagement process.

\section{Beyond Results}

As previously mentioned, the Strategic Action Plan offers both a timeframe and a lead organization for each initiative described. Ensuring that there is an on-going commitment by the Town and identified parties to these initiatives will be critical. As of right now, there is no formal monitoring program in place for the Action Plan and its 
associated initiatives. Oakville's Planning Services recommended to Council that staff report annually on the budget and timing implications around implementation of the Strategic Action Plan for Downtown Oakville. While this is proactive in that staff makes note that there will likely be on-going review, refinement and updates to the strategic initiatives, a formal monitoring and evaluation strategy may be advantageous to reinforce priorities and a long-term commitment to the plan itself, as well as curb any future digression.

The implementation of the actions that emerged from the DOSR is still relatively new, and as a result, the author is unable to provide solid data and research to evaluate the efficacy of the strategic review approach.

\section{Lessons Learned}

The strategic review process provides an opportunity for a high level of public input, engagement and consultation not generally undertaken in other regulatory planning approaches. They help to determine what actions are needed to ensure future success, and direct how and when these actions will be undertaken. It is important that embedded within the strategic review process is an outcome that includes an implementation monitoring aspect. This ensures that the municipality and wider community can see whether they have reached the goals and actions set forth in the action plan, or other resulting strategic review document. Furthermore, a strategic 
approach is also practical for application in other municipal initiatives beyond revitalization and vitality retention.

\section{ANALYSIS}

This research has offered insight into two real-world municipal strategies in two downtown Canadian contexts. Different local geographic and demographic contexts combined with economic trends have shown to impact not only the type of revitalization programs and policies developed, but also outcomes. Mid-sized, suburban cities have a larger pool of residents, not only within the local municipality but those surrounding as well, to draw to their historic downtowns. Small-sized cities, particularly those which are more rurally-based (as is the case of Brockville), do not have the same population numbers to support a bustling urbanized downtown, especially with increased competition from peripheral big box retail. However, natural heritage features and historic character are valuable tourist and retirement draws to small-city historic downtowns which may not be found in the more urbanized mid-sized city.

By conducting a strategic review, municipalities can gain a better understanding of the issues associated with their downtown area. It allows identification of "the good, the bad and the ugly" - ultimately what is working well, what is not working, what is having a negative impact, what is missing and what is desired in the future. A strong public engagement process is required to offer rich and diverse input on these issues, and that 
can be a challenge to municipalities if resource and budget limitations are a concern.

Community Improvement Plans can be more tangible in that they allow for specific action via programs, whereas a strategic review more or less an identifier for future action. However, if adequate public consultation has not been undertaken, CIPs can miss the mark of what the community really needs and wants. For example, the Heritage Signage Grant Program within Brockville's Downtown CIP was retracted due to lack of interest by the downtown business community. Additionally, if the programs introduced in the CIP are not beneficial to all aspects of the community - large, small, new and existing, commercial and residential - then its purpose in overall revitalization is lost.

Combining the approaches highlighted in these case studies would be most beneficial to other communities considering downtown vitality strategies. The combination provides a well-rounded method with the strategic review being the precursor to the CIP. By conducting a strategic review first, municipalities can identify the positive aspects, issues of concern and desired future action as indicated through stakeholder and public consultation, which was a strength of the DOSR. From this, a CIP can then be developed based on the identified strategic initiatives that evolved out of this public engagement process, ensuring that the programs developed in the CIP are necessary, relevant, and equitable across development scales. 
This research has also reinforced the importance of several key factors in successful revitalization strategy processes. In both cases there was a strong commitment from Council and municipal staff. While most responses identified Council and town staff generally, and named only one individual "champion" in one instance, the importance of champions cannot be ignored. They are important to jump-start and follow through with the process. A strong and organized BIA is also important to give downtown commercial owners a collective voice to influence revitalization directed strategies. Public engagement and consultation is essential in identifying areas that are perceived to need attention, as well as to discover what the community really wants for its downtown.

\section{CONCLUSION}

Municipalities across Canada are grappling with the negative impacts of urban sprawl, big box retail developments and global economic restructuring. As highlighted in the literature review, these impacts are traditionally seen in the decline of historic downtowns. As retail and commercial patterns change, so will the function of the downtown. The two case studies of Brockville and Oakville, Ontario have experienced these impacts and approached revitalization differently.

Brockville's economy was struggling with a transition from manufacturing to other industries, and combined with the global economic downturn, commercial retail and 
residential development in the downtown was negatively impacted. The City took a regulatory approach and the developed CIP incentives have proved successful in drawing some new development to the downtown, particularly with the new waterfront condo development currently taking place. However, the scale of development at which the CIP is aimed has not proved beneficial for existing developments and smaller-scale construction or building upgrades.

Oakville, on the other hand, has been fortunate enough to avoid many of the impacts of the global recession experienced in other historic commercial downtowns. Instead of trying to draw new development, Oakville opted to take a strategic approach and assess what was already there to create a strategic direction to ensure vitality in the future. While not enough time has elapsed to properly assess the implementation of the action items identified through the DOSR, the strategic review approach has proved an effective method for identifying areas of concern, strengthening existing assets, and engaging the public through consultation.

By combining both approaches, municipalities can gain a richer understanding of the issues facing their downtowns, and tailor CIP incentives and other programs to better address them. To adequately assess the implementation of the key actions identified in the DOSR's resulting Strategic Action Plan, further research must be undertaken. These cases are only two examples of downtown revitalization approaches, but a constant in both instances was dedication from Council and municipal staff, and the importance of 
the role of a champion. It is the hope that this research will provide other municipalities' with insight into the process behind these different approaches in order to better develop and undertake their own vitality-based strategies. 


\section{LIST OF REFERENCES}

Baade, R. A and Dye, R.F. (1988). Sports Stadiums and Area Development: A Critical Review. Economic Development Quarterly. Vol. 1, No. 3, p. 265-75

Bright, E. M. (2000). "Reviving America's Forgotten Neighborhoods: An Investigation of Inner City Revitalization Efforts". New York: Garland.

Brueckner, J. K. (2000). Urban sprawl: Diagnosis and remedies. International Regional Science Review. Vol. 23, Iss. 2, p. 160-171

Burayidi, M. A. (2001). "Downtowns: Revitalizing the centres of small urban communities". New York: Routledge

City of Brockville. (2007). Community Improvement Plan for Downtown Brockville. Retrieved 22 Nov 2010 http://city.brockville.on.ca/UploadedFiles/Final\%20CIP\%20Downtown\%20Brock ville\%20Sign\%20Grant\%20Program.pdf

Craig-Smith, S. J. (1995). The Importance and Problems of Waterside Regions. "Recreation and Tourism as a Catalyst for Urban Waterfront Redevelopment". Westport, CT: Praeger Publishers, p. 1-12

Faulk, D. (2006). The Process and Practice of Downtown Revitalization. Review of Policy Research. Vol. 23, No. 2

Filion, P. and Hammond, K. (2008). When Planning Fails: Downtown Malls in Mid Size Cities. Canadian Journal of Urban Research. Vol. 17, Iss. 2, p. 1-17

Filion, P.; Hoernig, H.; Bunting, T. and Sands, G. (2004). The Successful Few: Healthy Downtowns of Small Metropolitan Regions. Journal of the American Planning Association. Vol. 20, No. 3, p. 328 - 343

Florida, R. (2002). "The Rise of the Creative Class". New York, NY: Basic Books

Frankaviglia, R. V. (1996). "Main Street Revisited". lowa City: University of lowa Press

Franklin, A.W. (2001) The Impact of Wal-Mart Supercenters on Supermarket Concentration in U.S. Metropolitan Areas. Agribusiness, Vol. 17, Iss. 1, p. 105-114 
Frieden, B. J., and Sagalyn, L. B. (1989). "Downtown, Inc.: How America rebuilds cities" Cambridge, MA: MIT Press

Goetz, S. and Swaminathan, H. (2004). Wal-Mart and Country-wide Poverty. AERS Staff Paper No. 371

Grant, D. (2009). A Short History of Brockville, Ontario's First Incorporated Town. Retrieved 10 Jan 2010 http://brockvilleOoldOphotographoarchive.wordpress.com/a-short-history-ofbrockville-ontarios-first-incorporated-town/

Grodach, Carl and Anastasia Loukaitou-Sideris. (2007). Cultural Development Strategies and Urban Revitalization. International Journal of Cultural Policy. Vol. 13, No. 4, p. 349-370

Grogan, P. S., and Proscio, T. (2000). "Comeback Cities: A Blueprint for Urban Neighborhood Revival". Boulder, CO: Westview

Hechesky, L. (2005) Return to Main Street: An Assessment of the Main Street Revitalization Program. Masters thesis. The Graduate College of Marshall University

Hipler, H. M. (2007). Economic Redevelopment of Small-city Downtowns: Options and Considerations for the Practitioner. The Florida Bar Journal, p. 39-42

Huang, C.L.; Epperson, J.E.; Cude, B.J. and Woo B.J. (2002). Walmart Supercenter: The New Low-Price Food Retailer in Town. Choices, Vol. 6 Iss. 9, p. 40-41.

Jones, K. and Doucet, M. (2000). Big Box Retailing and the Urban Retail Structure: The case of the Toronto area. Journal of Retailing and Consumer Services. Vol. 7, Iss. 4, p. 233-247

McBee, S. (1992). "Downtown Development Handbook". Washington D.C.: Urban Land Institute

Ministry of Municipal Affairs and Housing. (2008). “Community Improvement Planning Handbook". Provincial Planning Policy Branch. Toronto, ON: Government of Ontario

Mulkeen, Maria L. (1997). Merchants and Business District Revitalization, A Case Study of Codman Square. Master's thesis. Massachusetts Institute of Technology, Department of Urban Studies and Planning. 
Neale, P.; Thapa, S.; Boyce, C. (2006). "Preparing a Case Study". Pathfinder International Tool Series. Watertown, MA: Pathfinder International

Pope, J. H. (1877). Illustrated Historical Atlas of the County of Halton. Toronto, ON: Walker \& Miles. Retrieved 2 Feb 2011. http://www.halinet.on.ca/localhistory/Page.asp?PagelD=26

Moulton, J. (1999). Ten Steps to A Living Downtown. Brookings Institution, Centre on Urban and Metropolitan Policy. Retrieved 3 Dec 2010 http://www.brookings.edu/es/urban/moulton.pdf

Robertson, K. A. (1999). Can Small City Downtowns Remain Viable? Journal of the American Planning Association. Vol. 65, No. 3, p. $271-283$

Robertson, K. A. (1997). Downtown Retail Revitalization: A review of American development strategies. Planning Perspectives. Vol. 12, p. 383-401

Robertson, K. A. (1995). Downtown Redevelopment Strategies in the United States: An end-of-the-century assessment. Journal of the American Planning Association. Vol 16, p. 429-437

Robertson, K. and Ryan, B. (2004). Downtown development on the metropolitan fringe. Economic Development Journal. Vol. 3, Iss. 4, p.16-24.

Rosentraub, M. S.; Swindell, D.; Przybylski, M.; Mullins, D. R. (1994). Sport and Downtown Development Strategy. Journal of Urban Affairs. Vol. 16. No. 3, p. 221-239

Rucker, D. G. 2001. An Evaluation of the Main Street Approach as a strategy for Conventional Economic Development. Masters thesis. University of Cincinnati, School of Planning of the College of Design, Architecture, Art and Planning.

Sanders, H. (2002). Convention myths and markets: A critical review of convention centre feasibility studies. Economic Development Quarterly. Vol 16, No.3, p. 195210

Sanders, H.T. (1992). Building the Convention City: Politics, Finance, and Public Investment in Urban America. Journal of Urban Affairs. Vol. 14, No. 2, p. 135159.

Sawicki, D. S. (1989). The Festival Marketplace as Public Policy. Journal of the American Planning Association. Vol. 55, No. 3, p.347-61 
Seidman, K. F. (2002) Inner City Commercial Revitalization: A Literature Review. Unpublished draft report. Retrieved 3 Dec 2010 http://ocw.mit.edu/NR/rdonlyres/Urban-Studies-and-Planning/11-439Spring2005/BAFBC134-3457-41A5-ACF9-2E5880567575/0/seidman4.pdf

Statistics Canada. (2006). 2006 Community Profiles, Brockville and Oakville, Ontario. Retrieved 23 Nov 2010.

http://www12.statcan.gc.ca/census-recensement/2006/dp-pd/prof/92591/details/page.cfm?Lang $=E \& G e 01=C S D \&$ Code1 $=3507015 \& G e 02=C S D \&$ Code2 $=$ $3524001 \&$ Data $=$ Count\&SearchText $=$ Oakville\&SearchType $=$ Begins\&Search $P R=01$ $\& B 1=A l 1 \&$ Custom $=$

Stone, K.E. (1997) Impact of the Wal-Mart Phenomenon on Rural Communities. "Increasing Understanding of Public Problems and Policies", Oak Brook, IL: Farm Foundation p. 189-200

The Brockville Museum. (2000). A Brief History of the City of Brockville http://www.brockvillemuseum.com/museum/index.cfm?ID=597

Town of Oakville. (2010). Background Facts Report. Retrieved 12 Feb 2011 http://www.oakville.ca/Media_files/planning10/lo-dosr-bkgrnd-10apr26.pdf

Town of Oakville. (2009). Livable Oakville Official Plan. Retrieved 12 Feb 2011 http://www.oakville.ca/Media_Files/planning10/loplan-parte-27jan10.pdf

Town of Oakville. (2010). Downtown Oakville Strategic Action Plan. Retrieved 22 Nov 2010 http://www.oakville.ca/Media_Files/planning11/lo-dosr-plan11jan18.pdf

Wood, R. (2003). Final Report - Leeds \& Grenville Jump Team Report. Retrieved 8 Feb 2010 http://leedsgrenville.com/en/aboutus/resources/FinalLeedsandGrenvilleJumpTea mReport.pdf

Yin, R. K. (2003). "Applications of Case Study Research", Second Edition. Thousand Oaks, CA: Sage Publications, Inc.

Zielenbach, S. (2000). "The Art of Revitalization". New York, NY: Garland Publishing

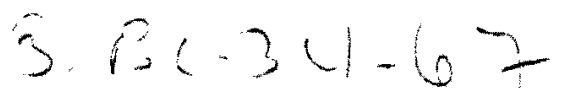

